\title{
PENGARUH PEMBERIAN BUNGKIL KEDELAI DAN SUPLEMENTASI ZINC, SELENIUM DAN VITAMIN E TERHADAP PENAMPILAN ESTRUS PADA \\ KAMBING PERANAKAN ETAWAH \\ (The Effect of Supplementation with Soybean Meal, Minerals and Vitamins on Estrus Performance of Etawah Crossbreed Goats)
}

\author{
Muktiani, A. ${ }^{1)}$ dan Kusumanti, $E^{2)}$ \\ ${ }^{1,2)}$ Staf Pengajar Fakultas Peternakan dan Pertanian Universitas Diponegoro \\ Fakultas Peternakan dan Pertanian, Universitas Diponegoro \\ Jalan Prof. H Soedarto, SH, Tembalang 50275, Semarang
}

Diterima : 22 Januari 2017 Disetujui : 13 Mei 2017

\begin{abstract}
ABSTRAK
Kambing betina yang akan dikawinkan perlu diberi pakan berkualitas yang cukup energi, protein, mineral dan vitamin agar dapat meningkat kinerja reproduksinya. Tujuan penelitian ini adalah mengetahui pengaruh suplementasi bungkil kedelai dan efektifitas suplementasi vitamin dan mineral terhadap tampilan estrus kambing Peranakan Etawah (PE). Enam belas ekor kambing (PE) yang siap dikawinkan digunakan dalam percobaan ini. Percobaan ini menggunakan rancangan acak lengkap dengan pola factorial $2 \times 2$, dan 4 ulangan. Faktor pertama adalah, $\mathrm{R}_{0}=$ ransum kontrol $(12 \% \mathrm{CP}$ dan $63 \% \mathrm{TDN})$, dan $\mathrm{R}_{1}=$ $A+100$ gram bungkil kedelai, sedangkan faktor kedua adalah $S_{0}=$ tanpa suplementasi dan $\mathrm{S}_{1}=$ disuplementasi dengan vitamin $\mathrm{E}$ dan mineral $\mathrm{Se}+\mathrm{Zn}$. Parameter yang diukur adalah konsumsi, pertambahan bobot badan harian dan kualitas ferning (lendir dari servic saat estrus). Hasil penelitian ini menunjukkan bahwa ada interaksi antara penambahan bungkil kedelai dan suplementasi mineral Zn, Se dan Vitamin E terhadap pertambahan berat badan kambing $(\mathrm{P}<0.05)$. Tidak ada perbedaan yang nyata akibat suplementasi $\mathrm{Zn}+\mathrm{Se}$ dan vitamin E pada ransum kontrol, namun suplementasi pada ransum yang ditambah bungkil kedelai menghasilkan pertambahan bobot yang lebih tinggi (54.10 vs 78.07 gram/hari). Skor ferning meningkat pada estrus ke metestrus pada ransum yang mendapat suplementasi mineral dan vitamin E, dan skor ferning terbaik terdapat pada kambing yang mendapat tambahan bungkil kedelai dan suplemen $\mathrm{Zn}$, Se dan Vitamin E. Disimpulkan bahwa penambahan bungkil kedelai dan suplementasi $\mathrm{Zn}+\mathrm{Se}$ dan vitamin E dapat meningkatkan pertambahan bobot badan serta memperbaiki penambilan estrus pada kambing, namun pada ransum yang kekurangan protein suplementasi tersebut tidak bermanfaat.
\end{abstract}

Kata Kunci: estrus, bungkil kedelai, selenium, vitamin E, peranakan etawa.

\section{ABSTRACT}

Female goat that would be mated need given high quality feed with enough energy, protein, minerals and vitamins to increase their reproductive performance. The purpose of this study was to determine the effect of supplementation with soybean meal, minerals and vitamins on estrus performance of Etawah crossbreed goats. Sixteen female goats used in these experiments. This experiment used a completely randomized design with $2 \times 2$ 
factorial pattern, and four replications. The first factor was, $R_{0}=$ control diet $(12 \% C P$ and $63 \% T D N)$, and $R_{l}=A+100$ grams of soybean meal, while the second factor was the $S_{0}=$ without supplementation and $S_{1}=$ supplemented with minerals $\mathrm{Zn}$, Se and vitamin $E$. The results of this study indicate that there was an interaction between the addition of soybean meal and supplementation $\mathrm{Zn}$, Se and vitamin $\mathrm{E}$ on weight gain $(P<0.05)$. There was no significant effect of mineral and vitamin $E$ supplementation on body weight gain at the ration control, but in the rations with soybean meal produces a higher weight gain (54.10 vs $78.07 \mathrm{~g} /$ day). Ferning scores increased in estrus to metestrus on rations with mineral and vitamin E supplementation, and the best ferning scores was on the goats with additional soybean meal and supplementation of $\mathrm{Zn}$, Se and vitamin E. It was concluded that the addition of soybean meal and supplementation with $\mathrm{Zn}$, Se and vitamin E may increase weight gain and improve estrus performance in goats, but this supplementation useless in rations with low protein content.

Keywords: estrus, soybeans meal, selenium, vitamin E, etawa crossbreed.

\section{PENDAHULUAN}

Pada pemeliharaan kambing betina untuk bibit, dibutuhkan pakan tambahan yang berkualitas tinggi menjelang dikawinkan (flushing). Menurut Burritt et al. (2012) flushing bertujuan memperbaiki kondisi tubuh dan hormon reproduksi. Flushing juga dapat memperbaiki tingkat ovulasi dan mengurangi kehilangan embrio di awal kehamilan (Martin et al., 2004).

Bungkil kedelai merupakan limbah industri yang kaya akan protein dan energi, yaitu mengandung protein kasar (PK) $46,74 \%$ dan total digestible nutrients (TDN) $74,76 \%$ serta kaya asam amino esensial (Philsan, 2010), sehingga bungkil kedelai layak diberikan pada ternak betina untuk memperbaiki kualitas pakan pada saat flushing. Selain protein dan energi, ternak juga membutuhkan mineral Selenium (Se) dan vitamin $\mathrm{E}$ untuk mendukung reproduksi, sedangkan mineral mikro lainnya yaitu Zinc (Zn), perlu ditambahkan karena $\mathrm{Zn}$ berperan penting dalam metabolisme nutrien dan sintesis protein (Fu-yu et al., 2007). Bahan pakan di Indonesia pada umumnya defisiensi $\mathrm{Zn}$ (Adriani et al., 2004). Pemberian nutrien yang cukup diharapkan dapat memperbaiki penampilan estrus kambing betina sehingga dapat meningkatan keberhasilan saat perkawinan.

Estrus adalah keadaan dimana ternak betina bersedia menerima pejantan untuk melakukan kopulasi. Estrus pada kambing berlangsung selama 12-36 jam (Lenira, 2009). Pada fase ini pengaruh kadar estrogen yang tinggi menyebabkan terjadinya pembengkakan vulva dan perubahan mukosa vagina (Akbar, 2010). Folikel de Graff membesar dan mengalami pematangan, sehingga bila terjadi pembuahan maka ternak akan bunting.

Penampilan estrus yang baik ditandai dengan kelimpahan lendir servik, kualitas lendir saat estrus (ferning) dan waktu birahi yang lama. Ferning adalah pola yang terlihat dalam spesimen kering lendir serviks, merupakan kristalisasi natrium klorida dalam lendir serviks yang berada di bawah pengaruh estrogen (Tanjung et al., 2015). Sutiyono et al. (2008) menyatakan bahwa ferning lendir serviks berkorelasi dengan tingkat estrogen. Pertambahan bobot badan yang baik juga mendukung penampilan reproduksi ternak. Tujuan penelitian ini adalah untuk mengetahui pengaruh suplementasi bungkil kedelai dan efektifitas suplementasi mineral dan 
vitamin terhadap penampilan estrus dan pertambahan bobot badan pada kambing Peranakan Etawah (PE).

\section{MATERI DAN METODE}

\section{Materi}

Penelitian dilakukan di kandang percobaan Fakultas Peternakan dan Pertanian Universitas Diponegoro Semarang pada bulan April sampai Mei 2016. Enambelas ekor kambing betina berumur 8-9 bulan dengan bobot badan rata-rata $21,25 \pm 2,12 \mathrm{~kg}$ digunakan dalam percobaan ini. Hewan uji tersebut ditempatkan dalam kandang individual berukuran $1 \times 0,8 \mathrm{~m}^{2}$ yang dilengkapi dengan tempat makan dan minum.

\section{Metode}

Rancangan percobaan yang digunakan adalah rancangan acak lengkap pola faktorial $2 \times 2$, dan 4 ulangan. Faktor pertama adalah :
$\mathrm{R}_{0}=$ ransum kontrol (12\% PK dan $63 \%$ TDN)

$\mathrm{R}_{1}=\mathrm{R}_{0}+100$ gram bungkil kedelai, $\mathrm{PK}$ $14 \%$ dan TDN 65\%)

sedangkan faktor kedua adalah :

$\mathrm{S}_{0}=$ tanpa suplementasi

$\mathrm{S}_{1}=$ dengan suplementasi $(\mathrm{Zn} 30 \mathrm{mg} / \mathrm{kg}$, Se

$0,2 \mathrm{mg} / \mathrm{kg}$ dan vitamin E $400 \mathrm{mg} / \mathrm{hari}$ ).

Kandungan nutrien masing-masing ransum perlakuan terlihat pada Tabel 1.

Ransum diberikan dua kali sehari yaitu pagi dan sore sebanyak $4 \%$ dari bobot badan (bahan kering). Lama pemberian ransum pelakuan adalah 3 minggu dengan masa preliem 1 minggu. Konsumsi pakan dihitung dengan cara pengurangi pemberian dengan sisa pakan pada keesokan harinya, keduanya diukur dalam bahan kering. Penimbangan bobot badan dilakukan pada awal dan akhir perlakuan. Pertambahan bobot badan harian dihitung dengan cara mengurangi bobot akhir dengan bobot awal kemudian dibagi dengan lama pemberian pakan.

Tabel 1. Formulasi dan Kandungan Nutrien Ransum Perlakuan

\begin{tabular}{lcc}
\hline & \multicolumn{2}{c}{ Perlakuan } \\
\cline { 2 - 3 } Bahan pakan & $\mathrm{R}_{0}$ & $\mathrm{R}_{1}$ \\
\hline & $\ldots \ldots \ldots \ldots \ldots \ldots \ldots \ldots \ldots \ldots \ldots \ldots \ldots \ldots \ldots \ldots \ldots \ldots \ldots$ \\
Jerami jagung & 45.00 & 40.99 \\
Dedak padi kasar & 21.00 & 20.50 \\
Polard & 10.00 & 9.32 \\
Onggok & 4.00 & 3.73 \\
Bungkil kelapa & 11.00 & 10.25 \\
Bungkil kelapa sawit & 4.00 & 3.73 \\
Bungkil kedelai & 2.00 & 8.70 \\
Molases & 3.00 & 2.79 \\
Jumlah & 100 & 100 \\
Kandungan nutrien : & & \\
Total digestible nutrients (TDN) & 63.05 & 64.43 \\
Protein kasar & 12.08 & 14.46 \\
Lemak kasar & 4.17 & 3.91 \\
Serat kasar & 21.93 & 20.83 \\
Bahan Ekstrak Tanpa Nitrogen & 51.47 & 50.44 \\
Abu & 10.30 & 10.16 \\
Calsium & 0.67 & 0.65 \\
Pospor & 0.47 & 0.49 \\
\hline Keran
\end{tabular}

Keterangan : Hasil analisis Laboratorium Ilmu Nutrisi dan Pakan Fakultas Peternakan dan Pertanian UNDIP (2015)TDN = dihitung berdasarkan rumus Sutardi (2001) 
Kualitas ferning lendir dari servik diamati selama 30 jam pada saat estrus. Pengambilan lendir serviks dilakukan pada empat fase yaitu proestrus, estrus, metestrus, dan diestrus pada satu kali siklus estrus. Vulva dibuka menggunakan speculum, kemudian lendir servik diambil menggunakan spuit $10 \mathrm{ml}$ lalu dioleskan pada object glass, dan di kering udarakan. Selanjutnya diamati menggunakan mikroskop pada perbesaran 100x. Tipologi ferning diukur berdasarkan skoring menurut Mardiati (2003) yang dimodifikasi, seperti terdapat pada Tabel 2.

Tabel 2. Skor tipologi ferning.

\begin{tabular}{cl}
\hline Skor & \multicolumn{1}{c}{ Definisi } \\
\hline 1 & $\begin{array}{l}\text { tidak ada ferning yang terbentuk (tidak ada kristalisasi, merupakan struktur yang berdinding } \\
\text { tebal berupa gelembung udara) } \\
\text { terdapat ferning dengan ukuran kecil dan tersebar } \\
\text { (terdapat kristalisasi yang hanya batang primer) } \\
\text { ferning terbentuk dengan batang primer, sekunder dan tersier yang menutupi kurang dari } \\
\text { setengah bidang pandang }\end{array}$ \\
\hline 4 & $\begin{array}{l}\text { ferning terbentuk dengan batang primer, sekunder dan tersier yang menutupi setengah } \\
\text { bidang pandang. }\end{array}$ \\
\hline 5 & $\begin{array}{l}\text { ferning terbentuk dengan batang primer, sekunder dan tersier yang menutupi } 75 \% \text { bidang } \\
\text { pandang. }\end{array}$ \\
\hline 6 & $\begin{array}{l}\text { ferning terbentuk dengan batang primer, sekunder, tersier dan kuarter yang menutup seluruh } \\
\text { bidang pandang. }\end{array}$ \\
\hline
\end{tabular}

Data pertambahan bobot badan yang diperoleh diolah menggunakan uji ragam, bila terdapat pengaruh perlakuan dilanjutkan dengan uji jarak berganda Duncan (Steel dan Torrie, 1981), sedangkan tipologi ferning dijelaskan secara deskriptif.

\section{HASIL DAN PEMBAHASAN}

Konsumsi BK kambing perlakuan berkisar antara 539,69 - 619,42 gram/hari (2,03-2,38\% dari bobot badan), tingkat konsumsi tersebut lebih rendah dibanding standar kebutuhan BK menurut NRC (1981) yang menyajikan tabel kebutuhan bahan kering kambing dara berbobot 20-30 $\mathrm{kg}$ dengan pertambahan bobot badan 50 gram/ hari sebesar 680 - 990 gram/hari atau berkisar 3,3 - 3,4\% dari bobot badan. Pengujian statistik menunjukkan bahwa penambahan 100 gram menghasilkan konsumsi bahan kering ransum yang tidak berbeda nyata. Hal ini disebabkan bentuk ransum berupa mash kering yang kurang disukai ternak, sehingga tingkat konsumsi terbatas.

Rata-rata pertambahan bobot badan kambing PE disajikan pada Tabel 3. Hasil pengujian statistik mendapatkan bahwa terdapat interaksi perlakuan perbedaan kualitas ransum dan suplementasi $\mathrm{Zn}$, Se dan vitamin $\mathrm{E}$ terhadap pertambahan bobot badan $(\mathrm{P}<0,05)$. Suplementasi $\mathrm{Zn}$, Se dan vitamin $\mathrm{E}$ pada ransum kontrol tidak berpengaruh nyata pada pertambahan bobot badan harian (39.06 vs 38.11 gram/hari), namun suplementasi pada ransum yang ditambah bungkil kedelai menghasilkan pertambahan bobot badan yang nyata lebih tinggi (54.10 vs 78.07 gram/hari). 
Tabel 3. Pertambahan bobot badan kambing dara akibat perlakuan pakan.

\begin{tabular}{lccc}
\hline Perlakuan & Ransum Kontrol & Ransum Flushing & Rataan \\
\hline Tanpa suplementasi & $39.06^{\mathrm{c}}$ & $54.10^{\mathrm{b}}$ & 46.58 \\
Suplementasi $\mathrm{Zn+Se+Vitamin} \mathrm{E}$ & $38.11^{\mathrm{c}}$ & $78.07^{\mathrm{a}}$ & 58.09 \\
\hline Rataan & 38.59 & 66,09 & \\
\hline
\end{tabular}

Superskrip pada baris dan kolom yang sama menggunakan huruf kecil yang berbeda menunjukkan perbedaan yang nyata $(\mathrm{p}<0,05)$.

Ransum kontrol menghasilkan ratarata $\mathrm{PBBH}$ yang rendah $(38,59 \mathrm{~g} / \mathrm{hari})$, hal ini senada dengan hasil penelitian Mulyono dan Sarwono (2004) bahwa pemeliharaan kambing semi intensif, dengan pemberian pakan berkadar protein kurang dari $13 \%$ akan menghasilkan PBBH kurang dari 50 gram/hari. Zinc berperan dalam pertumbuhan terutama pada sintesis protein, apabila protein tidak mencukupi maka $\mathrm{Zn}$ kurang dimantaatkan tubuh. Hal ini menghasilkan kesimpulan bahwa suplementasi vitamin E dan mineral Se dan $\mathrm{Zn}$ pada ternak yang kekurangan protein tidak memberikan respon positif terhadap pertambahan bobot badan.

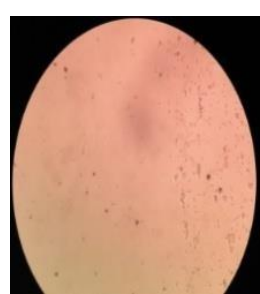

Skor 1

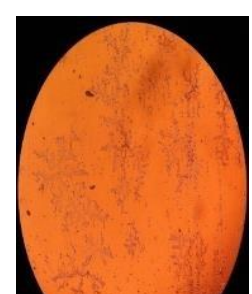

Skor 2

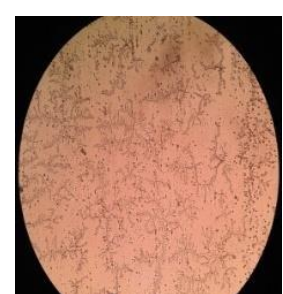

Skor 3
Kombinasi pemberian bungkil kedelai dan suplementasi Zn, Se dan Vitamin E menghasilkan rata-rata pertambahan bobot badan yang baik $(78,07 \mathrm{~g} / \mathrm{hari})$. Hasil ini tidak berbeda jauh dengan penelitian Munier (2010) bahwa kambing betina berbobot 18-19 $\mathrm{kg}$ yang diberi pakan tambahan berupa kulit buah kakao dan daun gamal menghasilkan pertambahan bobot badan antara 52,33 dan 70,42 gram/hari.

\section{Kualitas lendir servik (ferning)}

Pengamatan skor tipologi ferning pada kambing percobaan memperoleh hasil seperti tertera pada Ilustrasi 1. Sedangkan skor rata-rata ferning selama siklus estrus tertera pada Tabel 4.

Ilustrasi 1. Skor tipologi ferning kambing percobaan

Tabel 4. Skor Ferning pada saat Proestrus, Estrus, Metestrus dan Diestrus.

\begin{tabular}{lcccc}
\hline & \multicolumn{4}{c}{ Skor Fase Estrus } \\
\cline { 2 - 5 } & Proestrus & Estrus & Metestrus & Diestrus \\
\hline $\mathrm{R}_{0} \mathrm{~S}_{0}$ & 2,5 & 3,5 & 3,25 & 2,25 \\
$\mathrm{R}_{0} \mathrm{~S}_{1}$ & 2,5 & 4 & 3,75 & 3,5 \\
$\mathrm{R}_{1} \mathrm{~S}_{0}$ & 2,5 & 4 & 3 & 3,75 \\
$\mathrm{R}_{1} \mathrm{~S}_{1}$ & 1,25 & 3,75 & 4,25 & 2 \\
\hline
\end{tabular}

Keterangan : Tipologi ferning diukur berdasarkan skoring menurut Mardiati (2003) 
Berdasarkan Tabel 4, dapat dilihat skor ferning terbaik terdapat pada kambing yang mendapat ransum $R_{1} S_{1}$ yaitu ransum yang ditambah bungkil kedelai, dan disuplementasi Zn, Se dan vitamin E. Skor ferning meningkat pada estrus ke metestrus, yang berarti suplemenatsi mineral dan vitamin tersebut dapat memperbaiki kualitas lendir dan memperpanjang masa estrus. Suplementasi Se dan Zn mampu mempengaruhi perkembangan sel granulosa. Sel granulosa merupakan salah satu sel penghasil hormon estrogen. Widiyono et al.(2011) menyatakan bahwa estrogen mampu meningkatkan sekresi lendir serviks yang merupakan salah satu indikasi ternak berahi. Lendir serviks yang keluar mengandung protein, $\mathrm{NaCl}$ dan musin. Peningkatan kadar $\mathrm{NaCl}$ pada lendir serviks menyebabkan pembentukan tipologi ferning yang maksimal.

\section{KESIMPULAN}

Disimpulkan bahwa suplementasi Zn, Se dan vitamin $\mathrm{E}$ dapat meningkatkan pertambahan bobot badan serta memperbaiki penambilan estrus pada kambing, namun pada ransum yang kekurangan protein suplementasi tersebut tidak mampu memperbaiki pertambahan bobot badan.

\section{DAFTAR PUSTAKA}

Adriani, A. Sudono, T. Sutardi, IK. Sutama, dan W. Manalu. 2004. Pengaruh Superovulasi dan Suplementasi Mineral Seng Dalam Ransum Pada Induk Kambing Terhadap Pertumbuhan Anaknya. $J$. Pengembangan Peternakan Tropis, 29 : 177-183.
Akbar, B. 2010. Tumbuhan dengan Senyawa Aktif yang Berpotensi sebagai Bahan Anti Fertilitas. Adabia Press UIN, Jakarta.

Burritt, B., McNeal, L., Miller, R., Villar, F. 2012. Flushing Ewes Improves The Number of Offspring in a Commercial Range Management Operation. Journal of the NACAA. 5 http://www.nacaa.com/journal/index .php

Fu-yu, Xin., H. Ming-hai, L. Wen-li, L. Yan-qin, W. Ling-ling, S. Jie and Z. Ji-feng. 2007. Effect of different levels of zinc on blood physiological and biochemical parameters in stud holstein bulls. Chinese J. Anim. Nutr., 5:19.

Lenira, M. 2009. The Estrous Cycle in Does. Alabama Cooperative Extension. Alabama.

Mardiati, S.M. 2003. Kadar Na Lendir Serviks serta Kadar Garam Na dan K Lendir Mulut pada Berbagai Struktur Daun Pakis (Tes Ferning). Thesis. Universitas

Diponegoro,Semarang.

Martin, G.B., Milton, J. T .B., Davidson, R. H., Banchero-Hunzicker, G. E., Lindsay, D. R., and Blache. D. 2004. Natural methods for increasing reproductive efficiency in small ruminants. Animal Reproductive Science 82-83(1):231246.

Mulyono, S. dan B. Sarwono. 2004. Penggemukan Kambing Potong. Penebar Swadaya Swadaya, Jakarta.

Munier, F.F. 2010. Bobot hidup kambing betina peranakan etawah (PE) yang 
diberikan pakan tambahan daun gamal (Gliricidia sepium) dan kulit buah kakao (Theobroma cacao L.). Prosiding Seminar Nasional Teknologi Peternakan dan Veteriner.

National Research Council. 1981. Nutrien Requirments of Goats: Angora, Dairy, and Meat Goats in Temperate and Tropical Countries. National Academic Press, Washington DC.

Philsan. 2010. Feed Reference Standards. Fourth edition. Philippine Society of Animal Nutritionists, Laguna.

Steel, R.G.D. and J.H. Torrie. 1981. Principles and Procedures of Statistic. Mc Grow Hill Book Co. Inc. New York.

Sutardi, T. 2001. Revitalisasi peternakan sapi perah melalui penggunaan ransum berbasis limbah perkebunan dan suplemen mineral organic. Laporan Penelitian RUT VIII.1. LPPM Institut Pertanian Bogor, Bogor.

Sutiyono, E.T. Setiatin, S. Kuncara and Mayasari. 2008. Pengaruh pemberian ekstrak hipofisa terhadap birahi dan fertilitas pada domba yang birahinya diserentakkan dengan progesteron. J. Indonesian Tropical Animal Agriculture. 33(1):20-26

Tanjung, A.D; E. T. Setiatin and D. Samsudewa. 2015. Level of estrogen hormone and estrus performance of different postpartum estrus of jawa randu goat. $J$. Indonesian Trop. Anim. Agric. 40(2):87-92
Widiyono, I., P. P. Putro, P. Astuti dan C. M. Airin. 2011. Kadar estradiol dan progesteron serum, tampilan vulva dan sitologi apus vagina kambing bligon selama siklus birahi. $J$. Veteriner. 12 (4) : 263-268 